\title{
Strengthening Character Education Through the Natural School Leadership Curriculum
}

\author{
Trio Saputra ${ }^{1, *}$ Dasim Budimansyah $^{2}$ \\ ${ }^{1,2}$ Universitas Pendidikan Indonesia, Bandung, Indonesia \\ *Corresponding author. Email: putrario086@upi.edu
}

\begin{abstract}
Character Education is one of the fields of study that is integrated in Citizenship Education. Every nation needs character education to maintain its existence as a nation, so character education is a very important formulation, especially in strengthening one's identity as a nation. This study aims to describe: 1) the implementation of strengthening character education through the natural school learning curriculum, 2) The impact of strengthening character education through the natural school leadership curriculum in the character of students. This research was conducted at the Al-Karim Natural Elementary School, Lampung. This research uses a qualitative approach with a case study method, with data collection using participatory observation, in-depth interviews, and document analysis. The results showed that: 1) Character Education Strengthening Program at SD AL-Karim Lampung was carried out through a habituation process, Leadership Curriculum programs, and through partnership development involving three educational centers (schools, families and communities). 2) The Program for Strengthening Character Education through the Leadership Curriculum has an impact on the character of students' responsibility. This character is in student activities both in the school environment and outside the school.
\end{abstract}

\section{Keywords: Strengthening Character Education, Leadership Curriculum, Nature School}

\section{INTRODUCTION}

Character education is currently still a central issue that is the focus of education in Indonesia. The problems of character formation faced by the Indonesian people such as the culture of corruption that is still mushrooming, the character of the nation is still shaky and fragile, individual disobedience in obeying laws, customs and culture, as well as ethical violations that often occur and are encountered in our society [1]. This is an important note that character education must be an important priority for the Indonesian people in order to suppress the increasing character problems in society.

The Indonesian Child Protection Commission (KPAI) also released that since the early four months of 2019, 8 cases have been found with specifications for violence in the school environment. In addition, there were 3 cases of beatings, 8 cases of physical violence, 4 cases of children bullying teachers at school, and 12 cases of physical violence. In this case, the overall cases that occur are at the elementary school (SD) level with a percentage of $67 \%$ of all existing cases. This is a shared reflection that education today must continue to make improvements, especially in order to strengthen character education, both in a system and implementation in the field involving the government, schools, parents, community, and also students as the goal of character education. Gray added (2010) that at the ages of children to adolescents, they are very vulnerable to several character and ethical problems, narcotics problems, sexual harassment, violence, robbery, and others [2].

Basically, character is an important pillar in the life of the state [3]. On the other hand, the development of a nation must also be accompanied by character development and vice versa. In the perspective of Citizenship Education ( $\mathrm{PKn}$ ), character is one area that is also an integrative part of Civics science. Hoge (2002) suggests that civic education essentially requires the foundation of character education [4]. In this sense, both need to be emphasized so that the goal of being able to form good citizenship and character can be achieved.

The government has essentially issued a policy in the form of Strengthening Character Education (PPK) through schools. PPK places character values as an important dimension in education. There are five main character values, namely religious character, nationalism, independence, mutual cooperation, and integrity [5]. The 
focus of the PPK movement itself is: (1) Program structure, namely levels and classes, strengthening the ability of teachers and the school environment (2) Curriculum structure, namely character building activities that are integrated in learning (intracurricular), co-curricular, and extracurricular; (3) The activity structure is in the form of programs/activities that are able to synergize the 4 dimensions of character processing from Ki Hadjar Dewantara (mind, practice, heart, feeling).

One of the educational institutions (schools) that can be said to have a focus on the formation and development of children's character is the "School of Nature" educational institution. School of Nature is an educational concept that embodies education together with a learning curriculum with nature and the implementation of child-friendly education by accommodating various uniqueness and characteristics of children. Several other studies have shown that natural schools have a role, contribution, consistency in instilling character values in their students [6], [7], [8], [9]. Based on this description, this study aims to describe the explanation of character education at the Al-Karim Alam Elementary School in Lampung and also the impact of implementing the leadership curriculum on student character.

\section{THEORETICAL REVIEW}

\subsection{Strenghening Character Education}

Character education is a conscious and earnest effort from a teacher to teach values to his students [10]. Ki Hajar Dewantara explained that noble values or domains must be processed in the educational process, which include feeling, thinking, exercising, and exercising the heart. That is, education must be directed at processing the four domains [11]. Lickona (1991) emphasizes the importance of three components of a good character, namely: "knowing the good, loving or desiring the good, \& acting the good". Therefore, the way to form an effective character is to involve these three aspects [12] .

In order to prepare for changes whose movements cannot be predicted, the government makes a policy on "Strengthening Character Education (PPK)" as a form of effort to overcome degradation related to character in the current global era [13]. Strengthening Character Education, hereinafter abbreviated as PPK, is an educational movement under the responsibility of the education unit to strengthen the character of students through harmonization of heart, taste, thought, and sports activities with involvement and cooperation between education units, families and communities as part of the strengthening of character education. from the National Movement for Mental Revolution (GNRM) [14]. Through PPK, the formation of national character is carried out massively, systematically, and integratively which includes the entire education system, school culture and in collaboration with the community [15].

The PPK movement needs to integrate, deepen, expand, and harmonize various character education programs and activities that have been implemented up to now. Integration can be in the form of guiding activities in the classroom, outside the classroom, and outside the school (community/community); integration of intracurricular, co-curricular and extra-curricular activities; simultaneous involvement of school members, families, and communities; deepening and expansion can be in the form of addition and intensification of activities oriented to the development of student character, addition of student learning activities, and rearrangement of student learning time at school or outside school; then the alignment can be in the form of adjusting the main tasks of teachers, School-Based Management, and the functions of the School Committee with the needs of PPK [16].

The Ministry of Education and Culture explained that PPK is a continuation and continuity of the 2010 National Movement for National Character Education which is also an integral part of Nawacita. The PPK movement places character values as the deepest dimension of education that civilizes and civilizes education actors [5]. The Ministry of Education and Culture in 2017 identified 5 main character values that need to be developed as priorities, namely: religious, nationalist, independent, mutual cooperation, and integrity. These main characters can be achieved through three PPK approaches, namely through a classroom-based approach, a school culturebased approach, and a community-based approach [17].

\subsection{Nature School Leadership Curriculum}

The curriculum has a central position, namely as the center of the educational process [18]. Tyler (1949) states that each curriculum contains several important components, including: (1) objectives, (2) teaching materials, (3) teaching and learning processes, (4) evaluation [19]. In practice, schools can plan and develop a curriculum that still refers to the national curriculum. Curriculum development basically directs the applicable curriculum to the expected educational 
goals, with the hope that students can face their future [20]. Curriculum development includes the process of preparation, implementation, assessment and refinement. It contains educational selection activities, subject organization, instructional methods and learning experiences, as well as evaluation procedures [21].

School of nature is the name of an educational concept. Nasir [7] argues that natural schools are an effort to implement an education system that comprehensively integrates the concept of a balance between values, attitudes, knowledge, intelligence, skills, communication skills, and awareness of environmental ecology. In the application of the natural learning method, the curriculum used is the natural school curriculum which is principally based on the national education curriculum which was developed using the Qur'an and As-Sunnah as a foundation with the principle of "Think globally act locally", meaning that the natural school curriculum seeks to prepare a generation that can compete in the global world with an educational process that is organized using local wisdom so that students can recognize and utilize regional and national potential [22].

The curriculum applied to nature schools remains focused on the central curriculum, but also includes nature-based education with 4 pillars of nature schools, namely: 1. Morals Curriculum 2. Cognitive curriculum, using the spider web method, through active learning methods, discussions and making nature as a laboratory for students to learn directly from nature. Thus, children get a holistic understanding of the universe [9]. 3. Leadership curriculum, using the outbound method as a learning medium. 4 . Entrepreneurship curriculum, using the market day method or internship, so that students can interact with units, actors and the business environment, and can start a business early on [23].

Regarding the implementation of the Leadership Curriculum at the Natural School, it aims to educate and prepare future leaders. As for the activities, namely through outbound media as a learning medium, the teacher carries out practical out-bound activities with students. In this case, according to Martin \& Leberman [24] that the results of out-bound activities will be beneficial for students' personal growth such as self-confidence, cooperation, and also social responsibility. Procurement of leadership curriculum in natural schools is expected to be able to prepare the character of future leaders. In relation to this, according to Nasir, "Leadership in the future is the key to face the challenges of the world entering the 21 st century which is tougher, complex, interdependent, and full of technology" [25].

\section{METHOD}

This research uses a case study approach. The qualitative approach was chosen because in this study we wanted to explore in depth the problems or events in particular related to the implementation of character strengthening. The selected case study method relates to the programs, activities and processes that exist at Sekolah Alam [26] .

The data in the study were obtained through participatory observation with the researchers involved directly and participating in activities related to the implementation of the Leadership Curriculum program [26]. Researchers also conducted in-depth interviews as a means to further dig up any information from each respondent [27]. Finally, the researcher obtained data through documentation analysis to ensure that the documents obtained were authentic in relation to the research problems[28].

The data analysis technique in this research is through data reduction, data presentation, and finally through verification or drawing conclusions. these three components are interrelated and carried out continuously in the data collection of Milles and Huberman. In this study, in order to test the validity of the data, triangulation tests were carried out. Triangulation of data is used to determine the validity of a data. Triangulation test is used as a test of the validity of the information. So, something is called true if the truth represents many people [28].

\section{RESULT AND DISCUSSION}

\subsection{Strenghtening Character Education Trough Nature's School Leadership Curriculum}

Strengthening character education at SD Alam Al-Karim Lampung was carried out through programs that had previously been planned by schools and teachers. The majority of these programs are implemented using out-of-class learning through outbound. Specifically, the outbound program consists of hiking, camping, games (traditional and non-traditional), as well as social trips.

First, related to hiking activities, students travel on certain missions such as climbing hills, crossing rivers and also other long trips. Second, namely Camping which is carried out in groups, both small groups and large groups. The rules in this camping activity are divided into 
two groups, namely the upper-level group consisting of grades 4,5 , and 6 and the lower level consisting of grades $1,2,3$. This is done because each level in the Natural School has a different material content and character at each level. Third, namely games that are carried out as a means of training cooperation and cohesiveness considering that the period of children in elementary school age is a period of happiness that cannot be separated from playing activities. In this case, what distinguishes each game in the Leadership Curriculum is that it is carried out in a structured and planned manner by inserting characters in each game to be carried out. Fourth, namely Social Trip which is a social trip activity carried out as a form of activity in order to foster and also familiarize children to want and be involved in every social problem, such as doing fundraising or doing activities to clean up the sea, rivers, and forests. done together with the community. Social Trips are usually integrated with camping activities as a means of community service in the area where camping activities are carried out.

In addition to these programs, SD Alam AlKarim in order to strengthen character education makes habituation in every program implemented in the Leadership Curriculum. including through the habit of praying before doing any activity to train the students' religious spirit, then dividing the group trip by choosing a leader in each group to train the students' leadership and democratic spirit, giving rules such as not being allowed to litter and taking care of personal and group belongings. in every journey to train a caring and social spirit.

Finally, in every program implemented in the Leadership Curriculum, other parties are involved in order to support the process of strengthening the student's character, including parents or family and also the community. The involvement of parents in the implementation of the program includes being a teacher partner in guiding students, and also as an evaluator of the program implemented in order to intensify the program so that it can be carried out properly. Not infrequently, parents are also involved in schools in every program, such as in camping activities which are routinely carried out, usually parents are invited to participate in camping activities in order for parents to also participate in coaching and can also feel the closeness with their children. The community is usually involved in every program implemented, usually the school also invites communities, community organizations, religious leaders and the community to be presenters in existing programs.

According to the Ministry of Education and Culture, that strengthening character education is essentially carried out as an effort of mental revolution that is in line with the government's nawacita and is the axis of primary and secondary education that needs to be integrated, deepened and expanded, as well as harmonized with various character education programs and activities has existed up to now [5]. Hoge (2002) argues that Citizenship Education (Citizenship
Education) essentially requires a foundation of character education [4], so that the role of character education that is implemented or school-based also plays an important role, especially in order to shape the character of citizens as desired by a country.

Komalasari and Saripudin [29] state that character education is a habit, so that the formation of one's character requires communities of character in this case, namely schools that play a role through the learning process, habituation, extracurricular activities, and in collaboration with family and community in its development. . In this case, according to Budimansyah [30] that the process of habituation or habituation is the process of creating various situations and conditions that contain reinforcement that allows students in their educational units, at home, in their community, to get used to behaving according to values. On the other hand, habituation is the right method to be applied to individuals, especially at the beginning of moral development [31]. This makes it possible that character education can be well internalized because it is carried out early on.

In its implementation, Alam Al-Karim Lampung Elementary School also involves parties outside the school both from organizations, the community also involves families as an effort to further intensify the strengthening of student character education. This is that according to Hamzah \& Khomaeni [32] in order to improve and strengthen character, hard work and sincerity are needed and must involve all components of the nation, especially the educational trilogy, which includes parents, the community and also institutions, especially education itself. Lickona added that the character education process needs to involve family members and the community as partners in character building efforts. The involvement of partners outside the school has the aim that character education can be well stimulated because it involves all elements of education [33].

\subsection{The impact of strengthening character education through the natural school leadership curriculum in the character of students}

Strengthening character education through the leadership curriculum has an impact on students' selfcharacter which includes religious, integrity, independent, and leadership. This can be shown by the activities of students while at school in teaching and learning activities as well as outside, and also activities at home that can be observed and observed through reports made routinely by the school and also parents.

First, related to the impact of students' religious character can be observed through students' daily activities at school such as students' awareness in carrying out worship, as well as students' awareness of their role in being involved in helping others as in the social trip program. Other support is in the form of reports that are routinely made by the school in collaboration with parents of students who show progress 
in each grade level increase of students, especially in worship awareness. Second, in the character of integrity, it can be observed that students have self-skills as well as strong self-confidence, responsibility, and discipline towards time. This is shown by students especially in their activities at school such as the number of late students coming to a good school by arriving on time, awareness of obedience to existing rules at school, as well as preparedness in any case shown by students, especially in every leadership curriculum activity. . Furthermore, the independence of students is shown by the awareness of students in maintaining their personal belongings while at school. This has indeed become a school culture, especially every individual, both teachers, students, and others, is obliged to take care of personal belongings.

Finally, related to leadership character, students can clearly show through their activities both within the leadership curriculum program and outside it. Students show self-maturity in leading which can be seen from the better self-leadership of students from the increasing class of students and also student awareness such as willingness to help others and also have the initiative to lead which can be shown through the enthusiasm of students in every activity in the school.

In essence, the cultivation of character values through schools is an effective effort in order to equip students to have character values to be formed, including the character of responsibility. In line with this, Thompson (2004:2) in this case mentions that formalized character education also provides a way for the public who are bound by schools and the wider community to jointly develop a common understanding of the values desired for all children [34]. Citizens with character are the foundation of good governance. On the other hand, that citizens without character are a threat to society, nation and state. The integrity of every citizen is the only sure guarantee of good citizenship [35]. In addition, through character education, it is expected to create a society that is more organized, has a good understanding of citizenship, and is even more productive as part of the nation and state [36]. Thus, using schools as a means to shape individual character is a good effort in order to maximize character development for individuals.

Cooper (2003) states that outdoor education allows children to recognize nature, learn to face challenges, develop teamwork and negotiation skills, engage in creative thinking, learn to be responsible, analyze situations critically., and develop skills to solve problems (Harris, 2015). In addition, based on many studies, it shows that the active involvement of children in the natural environment as a learning space has an impact and is beneficial for cognitive, physical, affective, and moral development in children. A consistent opinion emerges from the literature that nature offers opportunities and experiences for engagement that contribute to children's well-being in various ways, such as enhancing physical, individual character, psychological, social, and emotional development (Adams \& Savahl, 2017).

Based on this theory, of course, in this case the programs designed and implemented by the Alam AlKarim Lampung Elementary School can be said to be one of the appropriate means or methods especially in the context of strengthening the character education of students in schools that participate in strengthening the character of citizens. state based on Pancasila. This of course can be in line with how the concept of Civics also has a focus on developing and instilling the character of Pancasila into its citizens as an effort to equip every citizen to become a good citizen. The use of the outbound method in the context of forming student character is also an alternative that can be done by schools, which include being able to grow student character, and also beneficial for the growth of student skills, one of the goals of which is as a provision that can be beneficial for their lives and can be useful for the community, nation and state.

\section{CONCLUSION}

Strengthening character education is essentially a means to be able to instill and also develop the nation's character which is packaged through schools. Al-Karim Natural Elementary School is one of the schools that also has strong integrity in instilling character values into its students at school. This integrity is implemented through the planning of programs that are included in the school curriculum. Leadership curriculum is one of the pillars of the curriculum that plays an important role in the formation of student character.

Through the Leadership Curriculum programs such as Hiking, Camping, Games, and Social Trips, it shows good progressivity with the growth of student characters such as increasing student religiosity, awareness of self and social responsibility as well as student independence, student integrity attitude, and also student leadership character. In addition to good program planning, strengthening student education is also carried out through a habituation process aimed at enabling students to train and familiarize themselves with good values in their daily lives. In addition, involving parents in the education and coaching process as well as program evaluation is a good effort, especially in the context of strengthening student character. Community involvement in this case also plays an important role, so that students also have an awareness of themselves as part of the community and the community also feels involved in the process of strengthening character education. This is of course in accordance with the movement to strengthen character education itself which also emphasizes the involvement of the educational trilogy in character strengthening, which consists of schools, families, and communities.

\section{ACKNOWLEDGMENTS}

The researcher expresses his gratitude for the cooperation and assistance, especially to Prof. Dasim Budimansyah, M.Si as a supervisor in this research. The researcher would also like to thank the principal, teachers, 
students, and staff at the Alam Al-Karim Elementary School in Lampung where the researcher collected the data.

\section{REFERENCES}

[1] R. F. Suryawan and D. D. Widyastuti, "Dynamics Of Character Education Through The Outbound Training Activities For Students On The Campus," Dinasti Int. J. Educ. Manag. Soc. Sci., vol. 1, no. 4, pp. 560-571, 2020, doi: 10.31933/DIJEMSS.

[2] Sudirman, "The 21st-Century Teacher: Teacher's Competence Within the Character Education Framework Towards A Cultural-Oriented Development and Promoting Tolerance," Int. Educ. Stud., vol. 12, no. 8, pp. 21-25, 2019, doi: 10.5539/ies.v12n8p21.

[3] A. Hidayati, M. Zaim, K. Rukun, and Darmansyah, "The Development of Character Education Curriculum for Elementary Student in West Sumatera," Int. J. Educ. Res., vol. 2, no. 6, pp. 189198, 2014.

[4] W. Althof and M. W. Berkowitz, "Moral education and character education: Their relationship and roles in citizenship education," J. Moral Educ., vol. 35, no. 4, pp. 495-518, 2006, doi: $10.1080 / 03057240601012204$.

[5] Kemendikbud, Konsep dan Pedoman Penguatan Pendidikan Karakter Tingkat Sekolah Dasar dan Sekolah Menengah Pertama. 2016.

[6] A. Basir and W. Ramadan, "Pembentukan Karakter Kepemimpinan Siswa Melalui Sekolah Alam (Studi Kasus di Sekolah Dasar Alam Muhammadiyah Banjarbaru)," J. Mu'adalah, vol. IV, no. 1, pp. 114, 2017, doi: http://dx.doi.org/10.18592/mu'adalah.v4i1.2118.

[7] E. A. Qibtiah, R. Retnowati, and G. H. Laihad, "Manajemen Sekolah Alam dalam Pengembangan Karakter Pada Jenjang Sekolah Dasar di School Of Universe," J. Manaj. Pendidik., vol. 6, no. 2, pp. 626-635, 2018.

[8] S. U. B. Astuti, "Implementasi Kurikulum Sekolah Alam Berbasis Pendidikan Islam Terpadu Di Kelas V Sdit Alam Nuris," J. Pendidik. Guru Sekol. Dasar, vol. 12, no. 6, pp. 1151-1160, 2017.

[9] A. N. Ummah, "Implementasi Budaya Sekolah Berbasis Karakter di Sekolah Dasar Alam Bengawan Solo," J. Pendidik. Guru Sekol. Dasar, vol. 6, no. 7, pp. 485-497, 2014.

[10] Elly Lanti, Media Pengembangan Pendidikan Karakter Bagi Siswa Sekolah Dasar. Gorontalo: Athra Samudra, 2017.

[11] M. Yaumi, Pendidikan Karakter: Landasan, Pilar, dan Implementasi. Jakarta: Prenamedia Group, 2016.
[12] E. Komara, "Penguatan Pendidikan Karakter dan Pembelajaran Abad 21," SIPATAHOENAN SouthEast Asian J. Youth, Sport. Heal. Educ., vol. 4, no. 1, pp. 17-26, 2018, [Online]. Available: www.journals.mindamas.com/index.php/sipatahoe nan.

[13] A. R. Fauzi, Z. Zainuddin, and R. Al Atok, "Penguatan Karakter Rasa Ingin Tahu dan Peduli Sosial melalui Discovery Learning," J. Teor. dan Praksis Pembelajaran IPS, vol. 2, no. 2, pp. 79-88, 2017, doi: 10.17977/um022v2i22017p079.

[14] M. L. ode Onde, H. Aswat, F. B, and E. R. Sari, "Integrasi Penguatan Pendidikan Karakter (Ppk) Era 4.0 Pada Pembelajaran Berbasis Tematik Integratif Di Sekolah Dasar," J. Basicedu, vol. 4, no. 2, pp. 268-279, 2020, doi: 10.31004/basicedu.v4i2.321.

[15] I. Agung, "Peran Fasilitator Guru Dalam Penguatan Pendidikan Karakter (Ppk)," Perspekt. Ilmu Pendidik., vol. 31, no. 2, pp. 106-119, 2017, doi: 10.21009/pip.312.6.

[16] Yetri and R. Firdaos, "Penguatan Pendidikan Karakter Berbasis Masyarakat Pada Sekolah Menengah Pertama Negeri (SMPN) Di Kabupaten Tulang Bawang Provinsi Lampung," vol. 8, no. Ii, pp. 267-279, 2017.

[17] Dalia Rosita Ria Yuliana, S. Hawanti, and O. Wijayanti, "Pelaksanaan Program Penguatan Pendidikan Karakter (PPK) Berbasis Kelas Melalui Manajemen Kelas di Sekolah Dasar,’ J. Temat., vol. Vol.9, no. No 2, pp. 109-114, 2016.

[18] Lismina, Pengembangan Kurikulum. Ponorogo: Uwais Inspirasi Indonesia., 2017.

[19] Alhammudin, Politik Kebijakan Pengembangan Kurikulum di Indonesia: Sejak Zaman Kemerdekaan Hingga Reformasi (1947-2013). Jakarta: Prenamedia Group, 2019.

[20] Dakir, Perencanaan dan Pengembangan Kurikulum. Jakarta: Rineka Cipta, 2010.

[21] E. Ismawati, Telaah Kurikuum dan Pengembangan Bahan Ajar. Yogyakarta: Penerbit Ombak, 2012.

[22] M. P. Safar, "Implementasi Kurikulum Sekolah Alam dalam Menjawab Tantangan Abad 21," Int. Conf. Moslem Soc., vol. 1, pp. 94-104, 2016, doi: 10.24090/icms.2016.1830.

[23] L. Aprilia and S. Trihantoyo, "Pembelajaran Berbasis Alam Dalam Membentuk Karakter Siswa Cinta Lingkungan Dan Berbasis Religi Islami Di Jenjang Sd Sekolah Alam Al-Izzah Krian," Manaj. Pendidik., vol. 6, no. 2, pp. 1-8, 2018.

[24] L. G. D'Amato and M. E. Krasny, "Outdoor Adventure Education: Applying Transformative Learning Theory to Understanding Instrumental Learning and Personal Growth in Environmental 
Education," J. Environ. Educ., vol. 42, no. 4, pp. 37-41, 2011, doi: 10.1080/00958964.2011.581313.

[25] M. Huda, K. S. M. Teh, N. H. N. Muhamad, and B. M. Nasir, "Transmitting Leadership Based Civic Responsibility: Insights from Service Learning," Int. J. Ethics Syst., vol. 34, no. 1, pp. 20-31, 2018, doi: 10.1108/IJOES-05-2017-0079.

[26] J. W. Creswell, Research Design Pendekatan Kualitatif, Pendekatan Kuantitatif, dan Mixed. Yogyakarta: Pustaka Pelajar. Yogyakarta: Pustaka Belajar, 2010.

[27] Sugiyono, Memahami Penelitian Kualitatif. Bandung: CV. Alfabeta, 2011.

[28] S. Al Muchtar, Dasar Penelitian Kualitatif. Bandung: Gelar Potensi Mandiri, 2015.

[29] K. Komalasari and D. Saripudin, Pendidikan Karakter. Bandung: Reflika Aditama, 2017.

[30] D. Budimansyah, Penguatan Pendidikan Kewarganegaraan dalam Perspektif Internasioal. Bandung: Widya Aksara Press, 2010.

[31] W. Sanderse, "Does Aristotle Believe that Habituation is only for Children?," J. Moral Educ., pp. 1-13, 2018, doi: 10.1080/03057240.2018.1497952.

[32] S. Buchori, M. Ibrahim, and A. Saman, "Pengaruh Character Education Training Melalui Outbound Training untuk Peningkatan Kejujuran dan Integritas," J. Psikol. Pendidik. dan Konseling J. Kaji. Psikol. Pendidik. dan Bimbing. Konseling, vol. 2, no. 1, p. 12, 2016, doi: 10.26858/jpkk.v2i1.2089.

[33] T. Lickona, "Eleven Principles of Effective Character Education Eleven Principles of Effective Character Education," J. Moral Educ., vol. 25, no. 1, pp. 93-100, 2006, doi: 10.1080/0305724960250110.

[34] Rukiyati, Y. C. N. Sutarini, and P. Priyono, "Penanaman Nilai Karakter Tanggung Jawab dan Kerjasama Terintegrasi dalam Perkuliahan Ilmu Pendidikan," J. Pendidik. Karakter, pp. 213-224, 2014.

[35] J. E. Burke, "Character Education for Citizenship," Relig. Edication, vol. 25, no. 3, pp. 223-227, 1930, doi: 10.1080/0034408300250307.

[36] B. H. Smith, "School-based Character Education in the United States," Child. Educ., vol. 89, no. 6, pp. 350-355, 2013, doi: 10.1080/00094056.2013.850921. 